\section{Christoph Wilhelm Hufeland (1762-1836)}

Christoph Wilhelm Hufeland, physician, author, editor and philanthropist, the centenary of whose death falls on August 25, was born at Langensalza in Thuringia on August 12, 1762, the son and grandson of court physicians at Weimar. After studying medicine at Jena and Göttingen, he qualified in 1783, his inaugural thesis being on the value of electricity in asphyxia. For the next ten years he remained in practice at Weimar, where he was brought into close contact with Goethe, Schiller, Wieland and Herder, as well as with members of the court. In 1793, he was invited by the Duke of Weimar to accept a professorship at Jena, and his lectures attracted considerable attention. In 1880 he succeeded C. G. Selle as royal physician at Berlin, where he became director of the Medico-Chirurgical College and senior physician to the Charité Hospital.

Hufeland was an extremely prolific writer, more than four hundred articles being attributed to him, but his best known works are "Makrobiotik" (1805) or the art of prolonging life, which was translated into every European language and passed through eight editions, and "Encheiridion Medicum ; or Manual of the Practice of Medicine", of which six editions were published, an English translation appearing in 1842. Of the four medical journals which he edited, the best known is the Journal der practischen Arzneikunde und Wundarzneikunst, which he founded in 1795 and edited until his death in 1836, after which it continued until 1844

Hufeland was an enthusiastic supporter of Jenner, and did much by his influence to diffuse the practice of vaccination throughout Germany, in addition to founding a vaccine institute at Berlin. He took an active part in the sanitary reorganization of Berlin, recommended the general use of warm baths and deprecated the abuse of spirits. In 1810 he founded a medical polyclinic, the first of its kind in Germany, for the treatment of the indigent poor, and for the next twenty-four years published annual reports of its activities. Finally, he did much useful work in combating popular errors concerning the Brunonian system of philosophy, mesmerism and phrenology. $\mathrm{He}$ was generally regarded as one of the noblest characters of his age.

\section{Sudden Deaths and Suicides in Russia}

According to the Gazette des Hôpitaux of August 25,1836 , official reports show that during the course of 1832,405 persons, of whom 324 were men and 81 women, died a sudden death in St. Petersburg. In 1833 the figures were considerably higher; 569 such deaths (353 in men and 216 in women) being registered. Most of these deaths were the result of intemperance. It is rare in St. Petersburg, the report continues, as in all the large towns in Russia, for public rejoicing not to cause the death of a large number of individuals. In 1833, for example, 78 men and 24 women were picked up in the streets of the capital whose deaths were due to drunkenness and cold. It is a well-known fact that in Russia, those who are so imprudent as to fall asleep in the open air after excessive consumption of strong drink never wake up again. In the course of the triennium 1831-33, 104 suicides were committed in St. Petersburg. It was noted that young persons made use of firearms or sharp instruments almost exclusively, while old people preferred drowning or hanging.

\section{Societies and Academies \\ Dublin \\ Royal Dublin Society, June 23.}

P. O'ConNor: A contribution to knowledge of Irish fungi. A complete list of the fungi recorded by the author in Ireland during the past three years, with sites, dates and host plants and trees. A number of the species have not previously been observed in Ireland, and a few are new to the British Isles.

P. A. Murphy and J. B. Loughnane: A comparison of some Dutch and Irish potato mosaic viruses.

Phyllis Clinch, J. B. Loughnane and P. A. MURPHY : A study of the aucuba or yellow mosaic of the potato.

H. H. Poole and W. R. G. Atrins : The standardization of photo-electric cells for the measurement of energy. The cells and colour filters used for the measurement of daylight have been standardized by means of a standard filament lamp so as to enable the radiant power per square centimetre in various parts of the spectrum to be found in absolute units. The relatively low temperature of the standard source and the relatively large effect of errors in its assumed colour temperature reduce the accuracy of the results.

J. Lyons : The influence of chemical composition on the firmness of butter. The exceptional firmness of New Zealand and Australian butters as compared with Danish and Irish butters is attributed to the relatively low unsaturated fatty acid content and high stearic acid content of the former.

J. A. C. Teegan: The comparison of $\gamma$-ray intensities from radium preparations. A valve method of measuring the ionization current allows the natural leak to be compensated, and is very rapid and convenient for routine measurements.

\section{Paris}

Academy of Sciences, July 6 (C.R., 203, pp. 1-136).

Lucien CAyeux : The reticulated structure of the silica observed in pre-Cambrian phtanites and Suessonian phosphates.

Marin Molmiard : The yield of green plants as a function of the proportion of oxygen in the atmo. sphere. With the radish as the experimental plant, the maximum yield was obtained with an atmosphere containing 5 per cent of oxygen, and the high yield coincided with a more intense green. It is suggested that, with proportions of oxygen above 5 per cent, some oxidation of the chlorophyll pigment may take place.

SERge Winogradsky : Researches on the morphology and physiology of Azotobacter in the soil.

Pierre LeJay : New determinations of the acceleration of gravity in France. A table is given showing the values of $g$ for 57 new stations.

Maurice Nicloux: The identification of ethyl alcohol.

MLle. Elisabeth Lutz: The solutions of the equation $y^{2}=x^{3}-A x-B$ in 9 -adic bodies.

ANDRÉ WeIL: The p-adic elliptic functions.

WolfGang DeEblin: The discrete chains of Markoff.

JEAN-ANDRÉ VILLE : The notion of the collectif.

E. J. Gumber : Floods and the theory of the greatest value. 
Christran Pauc: Some local properties of Euclidian continua.

Jules GÉHÉNIAU : The generalization of Th. De Donder of Hilbert's theorem of independence.

S. MandelbroJt and Norbert Wiener : Lacunous Fourier's series. Direct theorems.

Charles Platrier: The problem of Barré de Saint-Venant in a homogeneous medium which is deformed starting from a state of constraint.

Nicolas STOYko: The irregularity of the earth's rotation. From a comparison of data obtained at Charlottenburg $(0.35$ sec.) and at Paris $(0.39$ sec.) over the period October 1934-August 1935, there appears to be a retardation in the rotation of the earth of $0 \cdot 37$ sec.

RENÉ Dugas: A definition of the validity of quantic mechanics.

PifrRe VernotTe : The theoretical dimensions of the cellular vortices of Bénard.

Lteon Dubar : The influence of the gases of the atmosphere on the electrical conductivity of cuprous oxide. After a preliminary heating in a vacuum, contact with oxygen causes a regular increase in conductivity. This increase is removed by admitting water vapour.

M. LAMBREy and S. KraUthamer : The abnormal combinations of frequencies of conversion values.

Emire Puerret : The properties of triodes with large diameter plate in very high frequencies. Triodes with plate of large diameter can be used for the production of oscillations of very short wavelength, and the frequency can be varied between certain limits as a function of the voltage of the plate. This arrangement is specially useful in measurements of dielectric constants.

J. Henrion : Dielectric losses in an alternating field of high frequency and molecular dimensions. The experimental results given show that the method can be advantageously applied to the determination of mean molecular dimensions.

J. Swrngedauw : A new electro-chemical method of preparing proteins in the isoelectric state.

ThÉODORE V. IONESCU: The true periods of vibration of ionized gases in the magnetic field.

JACQUES STOHR: An arrangement with selfinduction circuit for determining the derivative with respect to time of a function represented by an electric current.

Marcel Laporte and François Gans: The physical photometry of tubes containing luminescent gas.

ROBERT Bossuet: The search for the alkaline metals in natural waters. The waters examined came from Corsica, Algeria, Tunis and Madagascar. The results are classified under two headings : those containing all five alkali metals, and those not containing cæsium.

$$
\text { (To be continued.) }
$$

\section{Brussels}

Royal Academy (Bull. Classe Sci., No. 5, 1936).

L. Godeaux : Cyclical involutions of the third order and genus one belonging to an algebraic surface.

P. FOURMARIER : Some observations on slaty cleavage in the Palæozoic regions of north Devon and north Cornwall.

E. W. Beth : Proof of a theorem concerning the principle of the excluded third.
M. BARZIN : Note on M. E. W. Beth's proof.

G. HIRSCH : Logical foundations of the theory of probabilities.

B. Gambien : Study of the cubic surfaces which can possess Eckardt points.

L. FALLA : An involution of the second order, the groups of which belong to the radii of a linear complex.

Yvonne Dupont : Theory of elastic deformations in space-time.

J. VAN Mteghem : Intrinsic form of the conditions of compatibility. Application to the calculation of potential discontinuities.

M. DÉsirant and A. Minne : Researches on the 'fluctuation bands' of the diatomic vapour of tellurium.

\section{Geneva}

Society of Physics and Natural History, June 4.

Arnold Pictet : The heredity of a novelty in fur : the silver guinea pig.

Charles BaEhNI : A case of generic convergence in the Iridaceæ. Normal Geissorhiza and abnormal Antholysa.

PaUL Rossier : (1) The calculation of the apparent diameter and effective wave-length of stars. (2) The effective photographic wave-length. (3) The width of the lines of stellar hydrogen.

Fernand LÉvy: The local distribution of the pressures in an elastic medium.

L. W. Collet and Ed. Parejas : (1) Contribution to the study of the Salève Tertiary. (2 and 3 ) The region comprised between Esserts and Usses, and a general survey.

June 18.

A. Mercier : The relations between the spinorial and Clifford magnitudes.

R. WAVRE : The four logarithmic potentials of a circumference.

F. BEER : The extension of the Hadamard-Schmidt theorem to the case of the logarithmic potential created by a real body in a complex domain.

K. H. Meyer and Brentano: Researches on maize starch.

E. C. G. STUECKELberg : The absolute electromagnetic potential as a new property of light.

\section{July 2.}

P. Wenger, Ch. Cimerman and G. Tschanun : The electrolytic microdetermination of zinc, and its application to brass.

Ch. Crmmrman and P. Wenger: The volumetric microdetermination of zinc.

E. Perroter and B. Susz: The Raman spectra of the cis and trans isomers of isoeugenol.

S. Fried and B. Susz: Note on the Raman spectrum of the trimethyl ether of oxyhydroquinol.

P. Rossier : Discussion of the spectrograms of the B5 stars.

J. BUFFle : Observations on the surface waters and deep waters of the canton of Geneva.

Dom Zrмmes : (1) The use of the nickel-nitroprusside reagent as an external indicator in the determination of reduced glutathione with iodine. (2) The amount of glutathione in some oil-producing plants : walnut, Brazil nut, hazel nut, almond and peanut. (3) The biological analogy between the bile acids and the sterols. The influence of the bile salts on the growth and morphogenesis of tadpoles. 


\section{Rome}

Royal National Academy of the Lincei (Atti, 23, 3-92; 1936).

U. Cisotti and A. Masotri : Ballast effects in space. G. A. MAGGI and B. FinzI : Conditions at the wave-front and harmonic electro-magnetic waves.

E. BoRтоцотті : Non-linear relations: geometry of a system of equations with partial derivatives of the second order. Preliminary (1).

O. Chisini : Branching curve of multiple planes,

G. Palamà : Two new generalizations of Vandermonde's determinant.

B. Caldonazzo: Free regulating source in the problem of a lamina.

G. LAMPARIELlo : Asymptotic irrotational motion of every stationary current of a perfect fluid subjected to conservative forces.

G. D. Mattioli : Second form of the equations of turbulence according to the hypothesis of a single direction of transport (1). Energetic equation of turbulence and conditions of integration of indefinite equations (2)

G. NeBbIA : Tracing the shapes of gradually varying permanent liquid currents.

E. Jolles: Derivatives of the azoxy-carboxylic acids.

C. Antontani and A. Spica Clerici : Glucidic metabolism of the mammary gland in vitro.

M. Fenoglio : Vogesite from Ginepro (Elba).

A. MessenI : Primary organizing sieve tissue of the secondary eambium.

G. NEGODI : Contribution to the cariology of Calendula (L).

M. Ventura : Some embryological data of Sapium sebriferum (L.), Roxb.

(Atti, 23, 95-159.; 1936).

G. Andruetro: New expression for the total curvature of a surface (1). Geodetically parallel lines and hyper-surfaces (2).

E. BonтоlotтI : Non-linear relations : geometry of a system of equations with partial derivatives of the second order. Intrinsic properties of the system (2).

U. BRoGGI : Determinant functions and polynomials of Laguerre.

L. Crocco : New function of a current for the study of the rotational motion of gases.

G. KRALL : Equations of vibratory motion of a bridge traversed by inert and pliant loads (I). Limits for the vibrations of any bridge traversed by mobile loads with uniform motion (2).

A. Masotiti : Planar motions produced from two vortex sources.

A. BARONI : Sulphide, selenide and thioselenide of thiocyanogen. The preparation of $\mathrm{Se}_{2}(\mathrm{CNS})_{2}$, of $\mathrm{SeS}(\mathrm{CNS})_{2}$ and of $\mathrm{S}(\mathrm{CNS})_{2}$ is described. All these substances polymerize readily at ordinary temper. atures.

O. Bottrini : Thermal decomposition of $\mathrm{NH}_{4}$-clays.

E. Parisi and G. DE VITo : Contribution to the knowledge of the ripening of cheeses. Polypeptides containing phosphorus (2). By the action of proteolytic enzymes fragments of relatively low molecular weight, which contain practically all the phosphorus of the original substance, are broken off from the casein molecule.

M. BENAzZI : Influence of the cephalic region on the movement and sensitivity of tricladic Planaria.

T. PERRI : Growth of the crystalline in anurid Amphibia (2). Experiments on Rana esculenta.

\section{Official Publications Received}

\section{Great Britain and Ireland}

Department of Scientiflc and Industrial Research. Forest Products Research Records No. 11 (Timber Series No. 3): The Properties of Home-Grown Oak. Pp. ii + 14. (London: H.M. Stationery Office.) $6 d$ net.

Empire Cotton Growing Corporation. Report of the Executive Empire Cotton Growing to the Heting of the Administrative Council on July 28th, 1936. Pp. 6. (London: Empire Cotton Growing Corporation.)

The National Institute of Poultry Husbandry: Harper Adams Agricultural College. Bulletin No. 12: Turkey Production. By A.J.

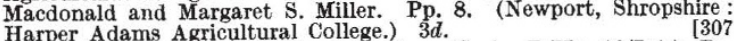
Anarchy or Peace? By Lord Davies. (Series D/No. 10/Int.) ${ }_{\text {Pp. }}^{\text {Pp. }}$ Anarchy or Peace ? By Lord Davies. City of Leicester Museum and Art Gallery. Thirty-second Report to the City Council, 1st April 1935 to 31 st March 1936. Pp. $32+2$ to the City Council, 1st April 1935 to 31st March 1936. Pp. $32+2$ plates. (Leicester: Museum and Art Gallery.) (England). Report Committee on Bird Sanctuaries in Royal Parks (England). Report for 1935. Pp. 27. (London: H.M. Stationery Office.) 6 . net . 317 The Scientiflc Proceedings of the Roya of Lichens found in Ireland (N.S.), No. 36: The Chemical Constituents of Lichens found in Ireland Buellia canescens, Part 2. By P. A. Spillane, Dr. J. Keane and
Dr. T. J. Nolan. Pp. 333-343. (Dublin: Hodges, Figgis and Co. London: Williams and Norgate, Itd.) 18.

\section{Other Countries}

Transvaal Museum. Report for the year ended 31 March 1936.

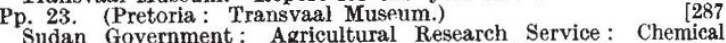
Analytical Section. Report of the Government Chemist for the Year 1935. (Chemical Section: Publication No. 78.) Pp. 23. (Khartoum Agricultural Research Service.) Memoirs of the Faculty of Science and Agriculture, Taihoku Imperial University. Vol. 18, No. 1 (Mathematics No. 18): On a Pair of Surfaces mutually Related (3) (4). By Sôzi Matumura. Pp. 19. Vol. 18, No. 2 (Mathematics No. 19): : Uber Flächen und Kurven (16), Uber Eilinien und Eiflächen; Beiträge zur Geometrie der Kreise und
Kugeln (16), von Sôzi Matumura. Pp. 21-74. (Taihoku: Taihoku Kugeln (16), von Sôzi Matumura. Pp. 21-74. (Taihoku : Taihoku
Imperial University.) Bernice P. Bishop Museum. Bulletin 137: Dinoflagellates of the Coastal Waters of the Western Pacific. By Anton Böhm. Pp. 54. Bulletin 138: Ethnology of Futuna. By Edwin G. Burrows. Pp. iv + 239+11 plates. Bulletin 139 : Marquesan Insects ; Environment. By A. M. Adamson. (Pacific Entomological Survey : Publication 9.) By Herbert E. Gregory. Pp. 52. (Honolulu : Bernice P. Bishop Museum.)

Bernice P. Bishop Museum. Occasional Papers. Vol. 11, No. 15 Native Trade in Southeast New Guinea. By Laura Thompson Tueting. Pp. 43. Vol. 11, No. 16: Effect of X-Rays on Regeneration of Chelipeds of Atya bisulcata. By Charles Howard Edmondson. Pp. 15. Vol. 11, No 17: Society Islands Pounders. By Henry Silverthorne. Pp. 17. Vol. 11, No. 18: Check List of the Serphoidea Bethylidæ and Anteonidæ of Oceania. By Robert Fouts. Pp. 15. Vol. 11 No. 19: The Hawaian Silverswords: Systematics, Affinities-and Phytogeographic Problems of the Genus Argyroxiphium By David D. geographic Problems of the Genus Argyroxiphium. By David D. Keck. Pp. 38. Vol. 11, No. 20 : Contribution to the Mosses of Fiji. By Edwin B. Bartram. Pp. 30. Vol. 11, No. 21: Notes on the Flora and Fauna of Lehua and Kaula Islands. By Edward L. Caum. Pp. 17. Islands and Mangareva. By A. W. Exell. Pp. 4. Vol. 11, No, 23: Islands and Mangareva. By A. W. Exell. Pp. 4. Vol. 11, No. 23: A New Species of Schiedea. By Edward L. Caum and Edward Y Hosaka. Pp. 5. Vol. 12, No. 1 : Review of the Genus Orochlesis
(Coleoptera, Curculionidæ). By Elwood C. Zimmerman. Pp. 19.
Vol. 12, No. 2: Amarantaceæ of Southeastern Polynesia. By K. Vol. 12, No. 2: Amarantaceæ of Southeastern Polynesia. By K.
Suessenguth. Pp. 10. Vol. 12, No. 3: Baridinæ of Southeastern Suessenguth. Pp. 10. Vol. 12, No. $3:$ Baridinæ of Southeastern
Polynesia (Coleoptera, Curculionidæ). Polynesia (Coleoptera, Curculionidæ). By Elwood C. Zimmerman.
Pp. 8. (Honolulu: Bernice P. Bishop Museum.) Pp. 8. (Honolulu : Bernice P. Bishop Museum. Bishop Museum. Special Publication 26: Proceedings, Bernice P. Bishop Museum. Special Publication 26 : Proceedings,
Hawaian Academy of Science, Tenth Annual Meeting, 1934-1935. Hawaiian Academy of Science, Tenth Annual Meeting, 1934-1935.
Pp. 21. (Honolulu : Bernice P. Bishop Museum.) Field Museum of Natural History. Anthropology Leaflet 33 . Archæology of South America. By .J. Eric Thompson. Pp. 160 +12

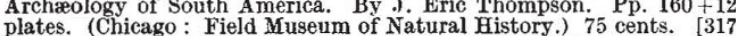
plates. (Chicago : Field Museum of Natural History.) 75 cents. $[317$ of the Argentine Ant in the United States and Suggestions for its of the Argentine Ant in the United States and Suggestions for its Control or Eradication. By M. R. Smith. Pp. 40. (Washington,
D.C.: Government Printing Office.) 5 cents.

Ministry of Agriculture, Egypt : Technical and Scientiflc Service. Bulletin No. 156: The Optimum Sugar Cane Planting Date in Egypt By Arthur H. Rosenfeld. Pp. $13+9$ plates. 3 P.T. Bulletin No. 179 Water-Weight-Changes in Export and Country Bales. By Dr. W Lawrence Balls. Pp. 27. 3 P.T. (Cairo : Government Press.) $[48$
Annual Report on Forest Administration in Malaya, including Brunei, for the Year 1935 . By J. P. Mead. Pp. iii $+60+4$ plates. (Kuala Lumpur : Government Printer.) 50 cents; 18. 2d. Proceedings of the Academy of Natural Sciences of Philadelphia Vol. 88. Notes on some South Asiatic Species of the Genus Cyornis By Erwin Stresemann and Rodolphe M. de Schauensee. Pp. 337-351. (Philadelphia : Academy of Natural Sciences.)
League of Nations. The Problem of Nutrition. Vol. $3:$ Nutrition in various Countries. (Series of League of Nations Publications. II Economic and Financial, 1936. II.B.5.) Pp. 271. (Geneva : League of Nations; London: George Allen and Unwin, Ltd.) $58.6 d$. $[58$ Union of South Africa: Department of Agriculture and Forestry. Bulletin No. 156: Seasonal Variations in the Freezing Point of South African Milk. By Dr. L. Denis-Lester. (Chemistry Series No. 143.) Pp. 14. 3d. Science Bulletin No. 153: The Composition of Pineapples. By J. C. Bodenstein. (Chemistry Series No. 146.) Pp. 14. $3 d$ 